\title{
FOUNDATIONS OF \\ POTENTIAL THEORY
}

BY

\section{OLIVER DIMON KELLOGG}

PROFESSOR OF MATHEMATICS IN HARVARD UNIVERSITY

CAMBRIDGE • MASSACHUSETTS - U.S.A.

WITH 30 FIGURES

DOVER PUBLICATIONS, INC. 